\title{
Öğretmen Adaylarının Anket Uygulamasına İlişkin Görüşleri*
}

\section{Gürol ZIRHLIOĞLU**}

Öz: Anket, başta sosyal bilimler olmak üzere pek çok alanda sistematik olarak veri toplamak için kullanılan bir yöntemdir. Önceden üzerinde çalış1lacak konu ile ilgili olarak hazırlanmış olan sorular katılımcılara yöneltilerek konu ile ilgili veri elde edilmeye çalışılır. Anket yoluyla pek çok konuda farklı türde veri toplamak mümkündür. Bu yöntem hızlı ve kolay veri elde etme yöntemlerinin başında gelmektedir. Hızlı ve ekonomik veri elde etmek şüphesiz ki yapılacak çalışma açısından önemlidir. Ancak bununla birlikte elde edilen verilerin niteliği, geçerlilik ve güvenirliği çok daha büyük önem arz etmektedir. Anketler ile sorulan sorular, özellikle davranış, tutum, duygu, tercih gibi konuları içeren sorular kişisel özellikleri ölçmektedir. $\mathrm{Bu}$ özellikler ise hızla değişkenlik gösterebilmektedirler. Bunun yanı sıra, yapılan çalışmanın güvenirliği açısından, anket sorularını cevaplayan kişilerin ne derece doğru ve güvenilir bilgi verdikleri de çok önemlidir. Gerek sorulan soru sayısı, soruların uzunluğu, niteliği, içeriği, ilgi çekiciliği, anlaşılabilirliği gibi hususlar cevaplayanların tutumlarını etkileyebilecek hususlardır. Çalışmada kullanılan veriler Yüzüncü Yıl Üniversitesi Eğitim Fakültesinin bazı bölümlerinde okumakta olan öğrencilerinden gönüllülük esasına göre elde edilmiştir. Yapılan bu çalışmada, anket yöntemi kullanılarak veri elde edildikten sonra, anket sorularını cevaplayan öğretmen adaylarının görüşleri ve bu konudaki davranışları belirlenmeye ve değerlendirilmeye çalışılmıştır.

Anahtar Kelimeler: Anket, katılımc1, güvenilir bilgi

\footnotetext{
*Bu çalışma 25-26 Kasım 2017 tarhlerinde Antalya’da düzenlenen “Uluslararası Multidisipliner Çalışmaları Kongresi”nde sözlü bildiri olarak sunulmuştur.

** Dr.Öğretim Üyesi, Yüzüncü Y1l Üniversitesi, Eğitim Fakültesi, Van, orcid.org/0000-0001-8687-1349, gurolyyu@gmail.com
} 


\title{
Pre-service Teachers' Opinions about Survey Methods
}

\begin{abstract}
The survey method is a method which is used in many areas, primarily in social sciences to collect data systematically. Questions prepared about the subject to work on are oriented to participants to obtain the relevant data for the subject. By using survey method, collecting data about lots of different topics is possible. This is a common method to obtain data quickly and easily. Undoubtedly, achieving fast and economic data is important for the specific projects. However, the quality, reliability and validity of the data is much more important. The questions asked about behaviors, attitudes, feelings, and choice particularly measure the personal characteristics. These characteristics may change very fast. Besides that, the accuracy and reliability of the participants' answers are very important for reliability of the study. Certain issues such as the number of questions, the length of the question, the nature, content, attractiveness, intelligibility can influence the attitude of the participants, when they answer the questions. The data were obtained voluntarily from the students who are studying in some departments in Yüzüncü Y1l University of Faculty of Education. In this study, after the data is obtained by using survey method, views of the participants and their behaviors are determined and evaluated.
\end{abstract}

Keywords: Survey, participant, reliable information 


\section{Giriş}

Anket, kişilerin bireysel farklılıklarını, davranışlarını, görüşlerini ve herhangi bir şeye karşı sahip oldukları tutumlarını belirleyebilmek için onlara yöneltilen sorular aracılığı ile bir iletişime girme yöntemidir (Balcı, 2010). Anket çalışmaları günümüzde başta eğitim bilimleri ve sosyal bilimler olmak üzere pek çok alanda yapılan çalışmalarda birincil kaynaklardan veri toplamak ve "gözlemleri standartlaştırmak" amacıyla kullanılan önemli araştırma yöntemlerinden birdir (Balc1, 2010; İslamoğlu, 2011; Oğur ve Tekbaş, 2003). Anket yöntemi ilk olarak 1880 yılında görüşlerine taraftar arayan Karl Marx tarafından posta anketi olarak uygulanmıştır (Berner, Bowers ve Heyman, 2002). Günümüzde ise çeşitli uygulama şekilleri ile diğer veri toplama yöntemlerine göre kısa sürede daha fazla veriye ulaşabilmek ve birincil kaynaklardan bilgi toplamak için sıklıkla kullanılan bir yöntemdir (Altunışık, 2008; İslamoğlu, 2002). Anketler, odak grup çalışmaları veya derinlemesine görüşmeler gibi daha kalitatif yöntemlerle daha ayrıntılı olarak incelenebilecek konuların belirlenmesine yardımcı olurlar (Berner ve di.̆., 2002).

Zaman içinde tekrarlanan anketler herhangi bir konu ile ilgili tutum veya sürdürülebilirliği ölçebilir (Berner ve diğ., 2002). Anket uygulamaları ile katılımcıların herhangi bir konu hakkındaki görüşleri, tercihleri, beklentileri, "tutumları, algıları" ve "kişilik özellikleri” hakkında bilgi sahibi olunabilir (Altunışık, 2008). Berner ve diğerleri (2002), anketlere verilen cevapların oransal bilgi verecek şekilde yorumlanmasının yanı sıra bazen de karşılaştırılabilir bir biçimde ölçülüp sunulabildiğini belirtmektedirler.

Berner ve diğerleri (2002), araştırmacıların (1) doğrudan, genellikle ölçülebilir soruların cevapları için, (2) anonimlik ve (3) rasgelelik nedenlerinden dolayı anket yolu ile veri elde ettiklerini belirtmektedirler. İyi hedeflenmiş ve iyi yürütülen bir anket çalışmasından elde edilen 
cevaplar varsayımda bulunulan konuya ilişkin bilgileri ortaya çıkarabilir veya onaylayabilir. Anonimlik araştırmacının belirli bir kişiye belirli bir yanıtı bağlamanın bir yolu olmadığı anlamına gelmektedir. Anonimlik özellikle anketin veya anket formunda yer alan bir sorunun konusu hassas veya tartışmalı olduğunda ve sonuçların kamuya açıklanması söz konusu olduğunda güvenilir ve "nesnelliğin daha yüksek olduğu" (Balc1, 2010, s.163) bilgiyi sağlayabilme açısından önemlidir. Rasgelelik ise araştırmacılara, nüfusun hedef kitlesini yansıtan sonuçları elde edebilmek için gerekli çabanın sarf edildiği yönünde bir güvence sunar. Bir anket çalışmasına kimlerin dahil edileceğine rastgele karar vermek, nüfus içindeki herkesin katılım için eşit şansa sahip olduğu anlamına gelmektedir (Berner ve diğ., 2002). Anketler ile elde edilen verilerin değişkenliği uygulanan anketin içeriğinden ziyade hedef kitleyi oluşturan bireylerin farklılıklarından kaynaklanmaktadır. Anket uygulamalarında her birey kendi görüşünü yansıtır (Altunışık, 2008). Araştırmalarda kullanılan anketlerin geçerliği için amaca uygun bir şekilde hazırlanmaları gerekmektedir. Bu nedenle sorularla, formun uzunluğuyla ve formun içyapısı ile ilgili hususlara dikkat edilmesi gerekmektedir. Anket formunun uzunluğunda zaman, katılımcının dikkati ve ilgisi dikkate alınmalıdır. Bu nedenle konuyla ilgisi olmayan ve analizlerde kullanılmayan sorulara yer verilmemelidir. Katılımcıya anketin içeriği hakkında bilgi verilmesi katılımcının ilgisini çekebilmek açısından önemlidir. Ancak verilen bu bilgiler katılımcıyı yönlendirecek tarzda bilgiler olmayıp, araştırmanın geneli ile ilgili olmalıdır (İslamoğlu, 2002). Sönmez ve Alacapınar (2014), bir anketteki soru sayısı ile ilgili olarak araştırmanın bağımlı ve bağımsız değişkenlerini kapsayacak şekilde olması gerektiğini, bunun dışındaki soruların ise gereksiz olduğunu belirtmektedirler.

Anket yoluyla yapılan çeşitli araştırmalarda birbirleriyle çelişen ve güvenirlik-geçerlik problemi olan çalışmalara rastlanabilmektedir. Elde edilen sonuçların güvenilir olabilmesi için araştırmada kullanılan verilerin güvenilir nitelikte olması gereklidir. Verilere uygulanan analiz 
yöntemlerinin uygunluğu ya da "mükemmelliği" verilerden kaynaklanan hataları telafi edebilecek nitelikte değildir (Altunışık, 2008). Benzer bir şekilde Büyüköztürk, Çakmak, Akgün, Karadeniz ve Demirel (2016) de anket uygulamalarında karşılaşılabilecek bazı sorunların önüne geçebilmek için; anketlerin kısa ve öz olması gerektiği, soruların bir amaca yönelik olması, kafa karıştırıcı ve yoruma açık olan sorulardan kaçınılması gerektiği, soruların basit cümlelerle ifade edilmesi gerektiğini belirtmektedirler (Büyüköztürk ve diğ., 2016).

Anket çalışmalarında uygulanan anket formlarından elde edilen verilerin hatalardan mümkün olduğu kadar arındırılmış ve katılımcıların gerçek düşüncelerini yansıttıkları varsayımı yapılmaktadır. Bu verilerin araştırmacının herhangi bir yönlendirmesi olmadan sadece katılımcıların kendi bağımsız görüşlerini yansıtıyor olması gerekmektedir (Altunışık, 2008). Bilimsel çalışmalarda yapılan araştırmaların varsayımları incelendiğinde tüm katılımcıların ankette yer alan soruları aynı şekilde anladıkları, sorulan soruya ilişkin bir ön bilgiye sahip oldukları, soruların, anket uygulanan kişi tarafından açık bir şekilde kelimelere döküldüğü, katılımcıların sorulara doğru cevap verdikleri gibi ifadeleri görmek mümkündür. Araştırma varsayımlarının ihmal edilmesi verilerin güvenirliği konusunda sorunların ortaya çıkmasına neden olabilmektedir (Altunışık, 2008; İslamoğlu, 2011). Ayrıca özellikle genel kitleyi ilgilendiren (market araştırmaları ve piyasa araştırmaları gibi) konularda katılımcıların anket maddelerini kendilerinin cevaplayabilmesi için okur-yazar olmaları da başka bir sınırlılıktır (Balcı, 2010). Çalışmaların bu sınırlılıklarla yürütülmesi araştırmacıların ön kabulleri olmak zorundadır. Çalışmanın güvenirliği ise öncelikle araştırmada yer alan katılımcıların duyarlılığına bağlıdır. Araştırmacılar yaptıkları çalışmalarda bu duyarlılığın var olduğu ya da yüksek olduğu varsayımı altında çalışmalarını yürütürler. Anket formlarının mümkün olduğu kadar standartlaştırılma gayretlerine rağmen pek çok hataya rastlamak mümkündür. Anket sorularının yanlış anlaşılması ya da hiç anlaşılmaması, cevap vermedeki 
isteksizlik, soruların tam okunmaması ya da hiç okunmadan cevaplandırılması gibi nedenler elde edilen verilerin ve dolayısıyla bu verilerden elde edilen bilgilerin güvenirliğinin düşmesine neden olmaktadır (Altunışık, 2008). Anket araştırmalarında, deneysel araştırmalarda olduğu gibi, değişkenler arasında kesin bir neden sonuç ilişkisi aramak zor olduğundan araştırmacıların vermiş oldukları cevapların doğru kabulü varsayımı özellikle dikkat edilmesi ve üzerinde özenle durulması gereken bir varsayımdır (Ünsal, 2003).

Anket araştırmalarının temel sınırlılıklarının yanı sıra uygulamada bazı güçlüklerinin de olduğu gözden kaçırılmaması gereken konulardan biridir. İnanç, sağlık, tuttukları parti gibi konularda katılımcılar kendi özel yaşamlarını ilgilendiren konularda farklı nedenlerden dolayı açık olamayabilirler (İslamoğlu, 2011). Bu da yapılan çalışmanın güvenirliğini olumsuz yönde etkileyebilmektedir. Benzer şekilde kişilerin tercihleri ya da beğenileri bazen zamana yayılan bir süreç içerisinde bazen de kısa zaman içinde değişebilmektedir. Bu durum ise elde edilen sonuçların genel geçerliği üzerinde olumsuz etkiler yapabilmektedir. Ancak kişisel tercihlerin, görüşlerin ya da özelliklerin belirlenmesi için anket çalışmaları hala eğitim bilimlerinde ve diğer sosyal bilimlerde etkili bir yöntem olarak kullanılmaktadır.

Anket yolu ile veri elde etmede araştırmacılar genellikle sorulara verilen cevapların gerçekçi olmadığı, özel hayata müdahale olduğu, soruların kendi görüşlerini yansıtmadığı, özellikle derecelendirme yapılmış seçeneklerde katılımcının baştan savma bir şekilde tüm sorularda aynı seçeneği işaretledikleri gibi ön yargılara kapılabilmektedir.

Çalışmanın Amacı: Yapılan bu çalışma ile anket çalışmalarında soruların hazırlanma şeklinden çok öğretmen adaylarının hazırlanan ve kendilerine uygulanan anket sorularına ilişkin görüşleri değerlendirilmeye çalışılmıştır. 


\section{Yöntem}

\section{Araştırma Modeli}

Çalışmada, geçmişte ya da halen var olan bir durumu var olduğu şekli ile betimlemeyi amaç edinen araştırmalar için uygun bir model olan (Karasar, 2008) tarama modeli kullanılmıştır.

\section{Çalışma Grubu}

Çalışmada kullanılan veriler Yüzüncü Y1l Üniversitesi Eğitim Fakültesinin Piskolojik Danışmanlık ve Rehberlik (PDR), Sınıf Öğretmenliği (SÖ), Bilgisayar ve Öğretim Teknolojileri Öğretmenliği (BÖTE), Müzik Öğretmenliği ve Okul Öncesi Öğretmenliği (OÖ) bölümlerinde okumakta olan öğrencilerinden gönüllülük esasına göre elde edilmiştir. Toplam 148 öğrenciye ölçme aracı uygulanmıştır. Araştırmaya katılan öğrencilerin cinsiyete ve bölümlere göre dağılımı Tablo 1'de belirtildiği gibidir.

Tablo 1.

Ankete katılan ögrencilerin cinsiyet ve bölümlere göre dă̆ılımı

\begin{tabular}{|c|c|c|c|c|c|c|}
\hline & PDR & SÖ & ВÖTE & Müzik & OÖ & TOPLAM \\
\hline & $\%)$ & $\%)$ & $(\mathrm{n} \quad \%)$ & $\%)$ & $\%)$ & $(\mathrm{n} \quad \%)$ \\
\hline Erkek & $11(20.8)$ & $14(26.4)$ & 7 (13.2) & $10(18.9)$ & $11(20.8)$ & $53(35.8)$ \\
\hline Kadın & 17 (17.9) & $24(25.3)$ & 13 (13.7) & $10(10.5)$ & $31(32.6)$ & $95(64.2)$ \\
\hline Toplam & $28(18.9)$ & $38(25.7)$ & $20(13.5)$ & $20(13.5)$ & $42(28.4)$ & 148 \\
\hline
\end{tabular}

Tablo 1'de görüldüğü gibi çalışmaya katılan öğrencilerin 28'i (\%18.9) PDR, 38'i (\%25.7) SÖ, 20'si (\%13.5) BÖTE, 20'si (\%13.5) Müzik ve 42’si (\%28.4) OÖ bölümlerindendir. Bu öğrencilerin 53’ü (\%35.8) erkek, 95’i (\%64.2) ise kadın öğrencidir.

\section{Verilerin Toplanması}

Verilerin elde edilmesi için öğretmen adaylarına araştırmacı tarafından hazırlanan anket formu uygulanmıştır. Anket formu, öğretmen adaylarının bazı genel bilgilerini içeren bir bölüm 
ile anket uygulamalarına ilişkin görüşlerine yönelik maddelerin yer aldığı bölümlerden oluşmaktadır. Anket formunda yer alan maddeler için öğretmen adaylarından “Katılmıyorum”, “Kararsızım” ve "Katılıyorum” seçeneklerinden birini işaretlemeleri istenmiştir. Herhangi bir neden sonuç ilişkisi ele alınmayacağından seçeneklerin puanlanması düşünülmeyip; "Katılmıyorum"=1, "Kararsızım"=2 ve "Katılıyorum"=3 olarak kodlanmıştır. Seçeneklerin her hangi bir puan değeri olmadığından ters kodlama/puanlama yapılmamıştır. Anket formunun katılımcılara ait bilgilerinin elde edildiğgi kısmında sekiz ve anket uygulamalarına ilişkin görüşlerinin alındığg kısımda ise 30 soru maddesi yer almıştır.

\section{Verilerin Analizi}

Verilerin analizinde genel tanımlayıcı istatistiklerin yanı sıra maddeler için tercih edilen seçenekler arasındaki ilişkiyi belirleyebilmek amacıyla "Çapraz Tablolar" yönteminden yararlanılmıştır. Conover (1999) (akt. Çilan, 2009, s.11) çapraz tablolar yönteminin genellikle kategorik değişkenler arasındaki ilişsiyi belirleyebilmek amacıyla kullanılan ve "doğal sayıların matris formunda düzenlendiği tablolar” olduğunu ve değişken kategorilerinin veri seti içerisinde kaç kez tekrarlandığını gösteren frekanslar olduğunu belirtir. $\mathrm{Bu}$ çalışmada değişkenler arasındaki ilişkilerin anlamlılık düzeyi ki-kare testi ile belirlenmiş olup alfa önemlilik seviyesi değeri 05 olarak alınmıştır. Hücrelerdeki gözlem sayısının beşten küçük olduğu durumlarda “Fisher's Exact Test” değeri kullanılmıştır.

\section{Bulgular}

Yapılan çalışmada öğretmen adaylarına yöneltilen anket formunda yer alan olumsuz yargı içeren sorulara öğretmen adaylarının çoğunlukla "katılmıyorum” yönünde cevap verdikleri, bunun yanı sıra olumlu yargı içeren sorulara ise "katılıyorum" yönünde cevap verdikleri belirlenmiştir. Öğretmen adaylarına yöneltilen maddelerden biri olan ve verilen 
cevapların gerçekliği yansıtması bakımından ele alınan "Çoğu zaman anketlere verdiğim cevaplar gerçekçi değildir” maddesine öğretmen adaylarının \%87.8’i katılmadıklarını belirtmişlerdir. Aynı şekilde katılımcılar "sağlık sorunları" ile ilgili olarak kendilerine yöneltilen anket sorularına büyük oranda (\%87.1) doğru yanıt verdiklerini, “aile yaşantıları" ile ilgili sorularda da benzer oranda (\%88.5) doğru yanıt verdiklerini belirtmişlerdir.

Çalışmada yer alan öğrencilerin verilen anketlerde yer alan maddelerin okunup okunmadığı hususuna yönelik olan "Verilen anketi çabuk bitirmek için çoğunlukla soruları okumuyorum" maddesine \%90.5 oranında katılmadıklarını, \%74.3’ü soru sayısı fazla dahi olsa sorulara "uydurma" cevaplar vermediklerini, \%79.7'si anket doldurmanın bir zaman kayb1 olmadığını, \%72.3'ü uygulanan anketler için yeterince zaman ayırmaya çalıştıklarını ve yaklaşık \%70’i ise soruların uzunluğuna bakmadan anket sorularını titizlikle cevapladıklarını belirtmişlerdir.

Öğretmen adaylarının \%61.5'i anketlerin yararlı olduğuna inandıklarını belirtirken yaklaşık \%24’ü bu hususta kararsız olduklarını ifade etmişlerdir. Benzer şekilde katılımcıların \%75.7'si anket çalışmalarını önemsediklerini, \%59'u anket çalışmalarının toplumu ilgilendiren konulara açılık getireceğini ifade etmişlerdir.

Çalışmada belirtilen bu olumlu yaklaşımların yanı sıra öğrencilerin olumsuz yaklaşımlarına ilişsin bulgular da elde edilmiştir. Öğretmen adaylarının yaklaşık \%41'i anketlerle toplanan bilgilerin yüzeysel olduğunu düşündüklerini, \%52'si kişisel bilgilerin sorulmasından rahatsızlık duyduklarını belirtmişlerdir. Kendilerine uygulanan anketler ile ilgili olarak araştırmacının, uygulama yapmadan önce, açıklayıcı bilgi vermesini önemseyen öğretmen adayları, anketlerin içeriği ile ilgili olarak kendilerine açıklayıcı bilgi verilmesinin 
cevaplarının gerçeği yansıtması bakımından önemli olduğunu belirterek bu duruma yaklaşık olarak \%84 oranında bir katılım göstermişlerdir.

Çalışmada uygulanan anket maddeleri arasındaki ilişkiler incelenerek bazı maddeler arasında istatistiksel olarak anlamlı bir ilişkinin olabileceği belirlenmiştir. Anket formunda yer alan, sorulara gerçekçi cevap verme durumu maddesi ile bu maddenin istatistiksel olarak anlamlı ilişkisinin olduğu belirlenen diğer maddelerin karşılaştırılmasına ait sonuçlar Tablo 2'de belirtildiği gibidir.

Tablo 2.

Sorulara gerçekçi cevap verme ile diğer bazı maddeler arasındaki ilişki

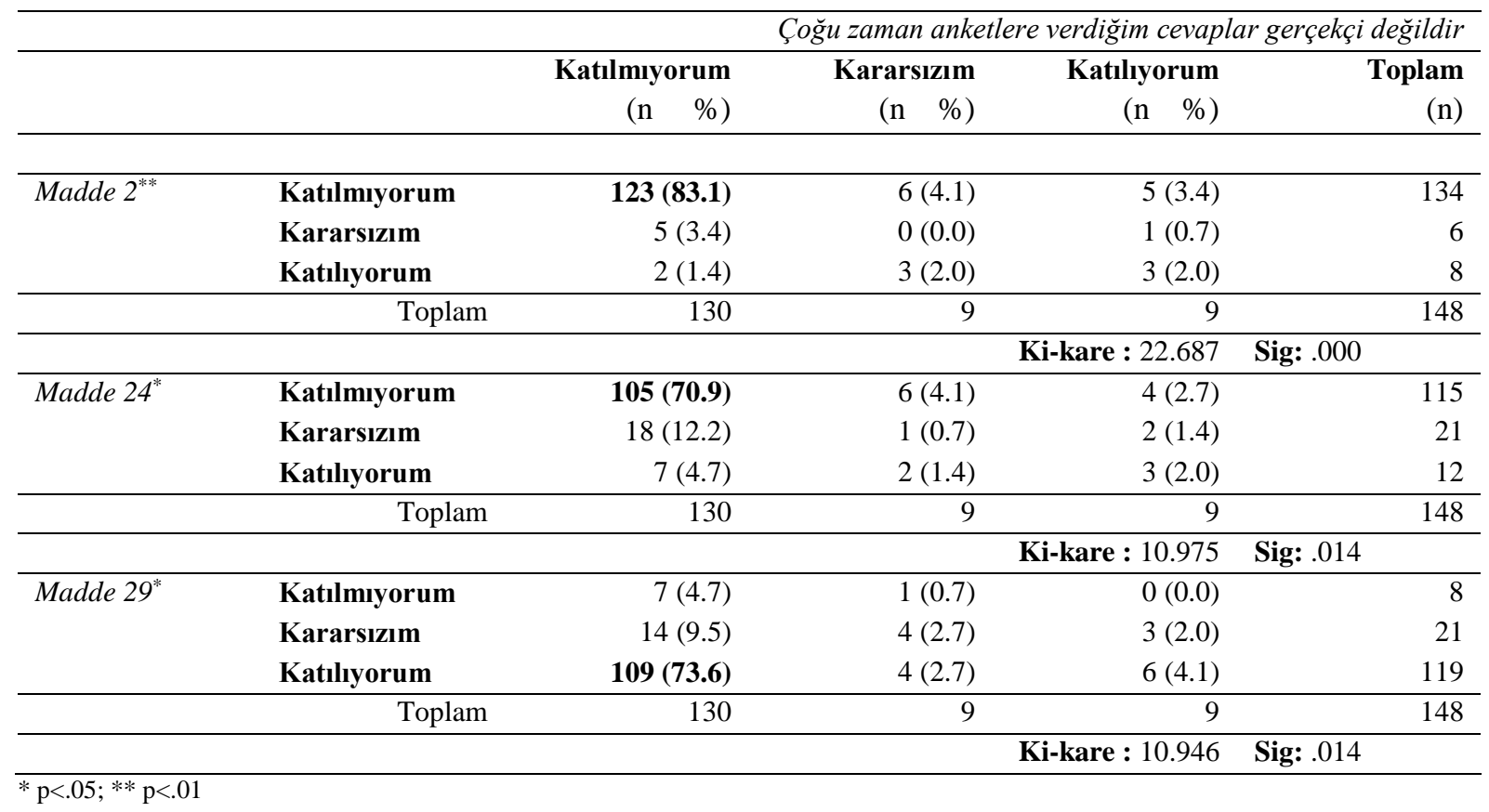

Tablo 2'de verilen değerler incelendiğinde “Çoğu zaman anketlere verdiğim cevaplar gerçekçi değildir" maddesine yönelik tercih edilen seçenekler ile madde 2 (verilen anketi çabuk bitirmek için çoğunlukla soruları okumuyorum), madde 24 (çok fazla sorunun olduğu anketlerde yer alan soruları okumam), ve madde 29 (anket sorularına verdiğim cevaplar gerçek düşüncelerimi yansıtır) maddeleri için yapılan tercihler birbirleri ile çok büyük bir oranda benzerlik göstermektedir. Söz konusu olan bu ilişkilerin istatistiksel olarak anlamlı olup olmadığının 
belirlenebilmesi amacıyla yapılan ki-kare testi sonuçlarına göre bu maddeler arasında anlamlı bir ilişki olduğu belirlenmiştir. Buna göre “Çoğu zaman anketlere verdiğim cevaplar gerçekçi değildir" maddesi ile madde 2 arasındaki ilişki $\alpha=.01$ düzeyinde anlamlı bulunurken, diğer maddeler ile olan ilişkinin $\alpha=.05$ düzeyinde olduğu görülmüştür. Anket formunda yer alan, anketi çabuk bitirmek için soruların okunmaması durumu maddesi ile bu maddenin istatistiksel olarak anlamlı ilişkisinin olduğu belirlenen diğer maddelerin karşılaştırılmasına ait sonuçlar Tablo 3'de verilmiştir.

Tablo 3.

Anketi çabuk bitirmek için soruların okunmaması ile diğer bazı maddeler arasındaki ilişki

\begin{tabular}{|c|c|c|c|c|c|}
\hline & & \multicolumn{4}{|c|}{ Verilen anketi çabuk bitirmek için çoğunlukla soruları okumuyorum } \\
\hline & & Katılmıyorum & Kararsizım & Katıliyorum & Toplam \\
\hline \multirow[t]{5}{*}{ Madde $24^{* *}$} & Katılmıyorum & $109(73.6)$ & $4(2.7)$ & $2(1.4)$ & 115 \\
\hline & Kararsızım & $17(11.5)$ & $2(1.4)$ & $2(1.4)$ & 21 \\
\hline & Katılıyorum & $8(5.4)$ & $0(0.0)$ & $4(2.7)$ & 12 \\
\hline & Toplam & 134 & 6 & 8 & 148 \\
\hline & & & & Ki-kare : 16.506 & Sig: .001 \\
\hline \multirow[t]{5}{*}{ Madde $25^{* *}$} & Katılmiyorum & $13(8.8)$ & $2(1.4)$ & $3(2.0)$ & 18 \\
\hline & Kararsızım & $3(2.0)$ & $1(0.7)$ & $1(0.7)$ & 5 \\
\hline & Katılıyorum & $118(79.7)$ & $3(2.0)$ & $4(2.7)$ & 125 \\
\hline & Toplam & 134 & 6 & 8 & 148 \\
\hline & & & & Ki-kare : 14.694 & Sig: .003 \\
\hline \multirow[t]{5}{*}{ Madde $27^{*}$} & Katılmıyorum & $15(10.1)$ & $2(1.4)$ & $4(2.7)$ & 21 \\
\hline & Kararsızım & $17(11.5)$ & $1(0.7)$ & $0(0.00)$ & 18 \\
\hline & Katıliyorum & $102(68.9)$ & $3(2.0)$ & $4(2.7)$ & 109 \\
\hline & Toplam & 134 & 6 & 8 & 148 \\
\hline & & & & Ki-kare : 9.775 & Sig: .022 \\
\hline \multirow[t]{5}{*}{ Madde $29^{* *}$} & Katılmıyorum & $6(4.1)$ & $0(0.0)$ & $2(1.4)$ & 8 \\
\hline & Kararsizım & $15(10.1)$ & $3(2.0)$ & $3(2.0)$ & 21 \\
\hline & Katılıyorum & $113(76.4)$ & $3(2.0)$ & $3(2.0)$ & 119 \\
\hline & & 134 & 6 & 8 & 148 \\
\hline & & & & Ki-kare : 15.182 & Sig: .002 \\
\hline
\end{tabular}

Tablo 3'de verilen değerler incelendiğinde "verilen anketi çabuk bitirmek için çoğunlukla soruları okumuyorum" maddesine yönelik tercih edilen seçenekler ile madde 24 , madde 25 , 
madde 27 (anketlerin veri toplamada önemli bir araç olduğunu düşünürüm), ve madde 29 için yapılan tercihler birbirleri ile çok büyük bir oranda benzerlik göstermektedir. Söz konusu olan bu ilişkilerin istatistiksel olarak anlamlı olup olmadığının belirlenebilmesi amacıyla yapılan kikare testi sonuçlarına göre bu maddeler arasında anlamlı bir ilişki olduğu belirlenmiştir. Buna göre "verilen anketi çabuk bitirmek için çoğunlukla soruları okumuyorum" maddesi ile madde 24, madde 25 ve madde 29 maddeleri arasındaki ilişki $\alpha=.01$ düzeyinde anlamlı bulunurken, madde 27 ile olan ilişkinin $\alpha=.05$ düzeyinde anlamlı olduğu sonucu elde edilmiştir. Anket ile elde edilen bilgilerin sosyal konulara açıklık getirmesi ile bu maddenin istatistiksel olarak anlamlı ilişkisinin olduğu belirlenen diğer maddelerin karşılaştırılmasına ait sonuçlar Tablo 4'de belirtildiği gibidir.

Tablo 4.

Anket ile elde edilen bilgilerin sosyal konulara açıklı getirmesi ile diğer bazı maddeler arasındaki ilişki

\begin{tabular}{|c|c|c|c|c|c|}
\hline \multicolumn{6}{|c|}{ Anket ile elde edilen bilgilerin birçok sosyal konuya açıklık getireceğini düşünürüm } \\
\hline & & Katılmıyorum & Kararsızım & Katılıyorum & Toplam \\
\hline \multirow[t]{5}{*}{ Madde $25^{* *}$} & Katılmıyorum & $9(6.1)$ & $4(2.7)$ & $5(3.4)$ & 18 \\
\hline & Kararsızım & $0(0.0)$ & $2(1.4)$ & $3(2.0)$ & 5 \\
\hline & Katılıyorum & $14(9.5)$ & $32(21.6)$ & $79(53.4)$ & 125 \\
\hline & Toplam & 23 & 38 & 87 & 148 \\
\hline & & & & Ki-kare : 15.453 & Sig: .001 \\
\hline \multirow[t]{5}{*}{ Madde $27^{* *}$} & Katılmıyorum & $10(6.8)$ & $6(4.1)$ & $5(3.4)$ & 21 \\
\hline & Kararsızım & $5(3.4)$ & $5(3.4)$ & $8(5.4)$ & 18 \\
\hline & Katılıyorum & $8(5.4)$ & $27(18.2)$ & $74(50.0)$ & 109 \\
\hline & Toplam & 23 & 38 & 87 & 148 \\
\hline & & & & Ki-kare : 27.029 & Sig: .000 \\
\hline \multirow[t]{5}{*}{ Madde $29^{* *}$} & Katılmiyorum & $14(2.7)$ & $2(1.4)$ & $2(1.4)$ & 8 \\
\hline & Kararsızım & $5(3.4)$ & $9(6.1)$ & $7(4.7)$ & 21 \\
\hline & Katıliyorum & $14(9.5)$ & $27(18.2)$ & $78(52.7)$ & 119 \\
\hline & Toplam & 23 & 38 & 87 & 148 \\
\hline & & & & Ki-kare : 14.509 & Sig: .003 \\
\hline \multirow[t]{5}{*}{ Madde $30^{* *}$} & Katılmıyorum & $7(4.7)$ & $3(2.0)$ & $1(0.7)$ & 11 \\
\hline & Kararsızım & $4(2.7)$ & $9(6.1)$ & $12(8.1)$ & 25 \\
\hline & Katılıyorum & $12(8.1)$ & $26(17.6)$ & $74(50.0)$ & 112 \\
\hline & & 23 & 38 & 87 & 148 \\
\hline & & & & Ki-kare : 20.664 & Sig: .000 \\
\hline
\end{tabular}


Tablo 4'de verilen değerler incelendiğinde “anket ile elde edilen bilgilerin birçok sosyal konuya açıklık getireceğini düşünürüm” maddesine yönelik tercih edilen seçenekler ile madde 25, madde 27, madde 29 ve madde 30 (yapılan anket çalışmalarını önemserim) için yapılan tercihler birbirleri ile benzerlik göstermektedir. Söz konusu olan bu ilişkilerin istatistiksel olarak anlamlı olup olmadığının belirlenebilmesi amacıyla yapılan ki-kare testi sonuçlarına göre bu maddeler arasında anlamlı bir ilişki olduğu görülmüştür. Buna göre "anket ile elde edilen bilgilerin birçok sosyal konuya açıklık getireceğini düşünürüm" maddesi ile diğer maddeler arasındaki ilişkinin $\alpha=0.01$ düzeyinde anlamlı olduğu belirlenmiştir. Kişisel bilgilerin sorulması ile açı̆̆a çıkma endişesi arasındaki ilişki Tablo 5'de belirtildiği gibidir.

Tablo 5 .

Kişisel bilgilerin sorulması ile açı̆̆a çıkma endişesi arasındaki ilişki

\begin{tabular}{llrrrr}
\hline & & \multicolumn{3}{c}{ Kişisel bilgilerimin sorulmasından hoşlanmiyorum } \\
\hline & & Katılmıyorum & Kararsızım & Katılıyorum & Toplam \\
\hline Madde 7 & Katılmıyorum & $38(25.7)$ & $17(11.5)$ & $63(42.6)$ & 118 \\
& Kararsızım & $7(4.7)$ & $1(0.7)$ & $1(0.7)$ & 9 \\
& Katılıyorum & $7(4.7)$ & $1(0.7)$ & $13(8.8)$ & 21 \\
\hline Toplam & 52 & 19 & 77 & 148 \\
\hline$*{ }^{*}<.05$ & & & & Ki-kare : 8.917 & Sig: .046 \\
\hline
\end{tabular}

Tablo 5'de verilen değerlere göre "kişisel bilgilerimin sorulmasından hoşlanmıyorum" maddesine yönelik tercih edilen seçenekler ile madde 7 (anket formunda kimlik bilgileri sorulmasa bile açı̆̆a çıkmaktan korkarım) için yapılan tercihler arasındaki ilişkinin istatistiksel olarak anlamlı olup olmadığının belirlenebilmesi amacıyla yapılan ki-kare testi sonuçlarına göre bu maddeler arasında anlamlı bir ilişki olduğu belirlenmiştir. Buna göre "kişisel bilgilerimin sorulmasından hoşlanmıyorum" maddesi ile madde 7 arasındaki ilişkinin $\alpha=0.05$ düzeyinde anlamlı olduğu sonucu elde edilmiştir. 


\section{Tartışma, Sonuç ve Öneriler}

Bu çalışmada, çeşitli amaçlar için yapılan araştırmalarda veri elde etme yollarından biri olan, anket yöntemiyle ilgili olarak öğretmen adaylarının görüşleri ele alınmıştır. Bu çalışmada yer alan katılımcıların anket ile veri toplama yöntemine doğru bir bakış gösterdikleri ve sağlık ve aile yaşantıları ile ilgili sorular da dâhil olmak üzere kendilerine yöneltilen çeşitli anket sorularını cevaplarken gerçekçi davrandıklarını belirtmişlerdir. $\mathrm{Bu}$ konunun katılımcılar tarafindan büyük bir çoğunlukla bu şekilde ifade edilmesi oldukça önem arz etmektedir. Zira bu durumla ilgili olarak katılımcıya güven duyma ve onların gerçek düşüncelerini yansıttıkları hususu önemli bir varsayım olup yapılan çalışmanın güvenirliği açısından önemlidir (Altunışık, 2008). Anketlere verilen cevapların gerçekliği ile verilen anketlerin çabuk bitirilmesi için soruların okunmaması arasındaki ilişkiye ilişkin veriler incelendiğinde öğretmen adayları her iki maddeye de büyük oranda katılmadıklarını ifade etmişlerdir. Bu durum, çalışmada yer alan öğretmen adaylarının görüşleri dikkate alındığında, Altunışık (2008)'ın belirttiği katılımcıya güven duyma ve onların gerçek düşüncelerini yansıtmaları varsayımına uygunluk göstermektedir. Aynı şekilde anketlere verdikleri cevapların gerçekçi olduğunu belirten katılımcılar soru sayısı fazla dahi olsa soruları okuduklarını belirtmişlerdir. Sorulara verilen cevapların gerçekçi olduğunu söyleyenler anket formundaki benzer nitelikte olan katılımcıların yapılan anketlere verilen cevapların gerçek düşüncelerini yansıttığ hususu ile ilgili maddeye büyük oranda katılım göstermeleri sorulara cevap verirken gerçekçi davrandıkları konusundaki tutarlılıklarını göstermektedir. Ancak burada dikkat edilmesi gereken husus soru sayısının fazlalığı konusunda her katılımcı grubunun aynı şekilde bir davranış gösteremeyebileceğidir. Nitekim, Sönmez ve Alacapınar (2014) bu konuyla ilgili olarak soru sayısının fazla olması durumunda katılımcıların cevap veremeyebileceğini, belli bir süreden sonra sıkılabileceklerini ve soruları gelişi güzel doldurabileceklerini belirtmektedirler. 
Balcı (2010), anket katılımcılarının kendilerine yöneltilen sorulara rastgele cevap verip vermediklerinin kontrolünün imkânsız olduğunu belirtmektedir. Ancak, yapılan çalışmada bu konuyla bağlantılı olarak katılımcılara yöneltilen "verilen anketi çabuk bitirmek için çoğunlukla soruları okumuyorum" maddesinden alınan dönütler incelendiğinde katılımcıların sorulan her soruya özen gösterdikleri, soruları cevaplandırırken dikkatli davrandıkları bilgisine ulaşılmıştır. Nitekim söz konusu olan bu madde ile ilişkili olan diğer maddeler incelendiğinde, aceleci davranmadan soruları okuduklarını söyleyen katılımcılar soru sayısı fazla dahi olsa soruları okuduklarını, anketlerin veri toplamada önemli bir araç olduğunun bilincinde olduklarını ve gerçekçi cevap verdiklerini ifade etmişlerdir. Ayrıca, "verilen anketi çabuk bitirmek için çoğunlukla soruları okumuyorum" maddesi ile ilişkili olan bir diğer madde anketin içeriği ile ilgili yeterli bilgi verilmesi halinde gerçekçi cevaplar vermeye çalışırım maddesidir. Bu durum aslında elde edilen verilerin güvenirliği için araştırmacıların araştırmış oldukları konu ile ilgili katılımcıya yapılan araştırma ile ilgili olarak eksiksiz bir kapak sayfası ve yönerge ile onları yönlendirmeyecek kadar bilgi vermelerinin önemini göstermektedir (Balc1, 2010; Büyüköztürk ve diğ., 2016). Katılımcıların hiçbir bilgi sahibi olmadıkları bir konuyla ilgili olarak bir fikir ortaya koymaktansa, bir fikir veya bilgi sahibi oldukları bir konuyla ilgili söyleyecekleri daha gerçekçi olacaktır.

Anket uygulamalarından nitelikli veri elde edebilmek için katılımcılara araştırma konusunun önemi hakkında yeterli bilgilendirme yapılması güvenilir bilgi elde edebilmek açısından önemlidir. Bu nedenle anketlerin uygulandığı kişilerin bu yolla veri elde etmenin öneminin bilincinde olması gerekmektedir. Nitekim bu yöntem, sosyal bilimlerde veri elde edebilmek ve elde edilen verileri standartlaştırmak için kullanılan önemli veri toplama yöntemlerinden biridir (Balcı, 2010). Çalışmada katılımcıların bu konu ile ilgili bilinçli 
oldukları ve anket çalışmalarını önemsedikleri, yapılan bu türden çalışmaların toplumu ilgilendiren konulara açıklık getirecek nitelikte olduğunun bilincinde oldukları görülmüştür.

Anket tekniği yapısal özelliklerinden ötürü sınırlı bilgi sağlayabilmektedir. Anketlerle toplanan bilgiler incelenen konuyu derinlemesine ele alan bilgiler değildir. Anket yöntemi ile daha çok konuyla ilgili yüzeysel bilgilere ulaşmak mümkündür (Balcı, 2010). Çalışmada yer alan katılımcılar da buna benzer nitelikte anketlerle toplanan bilgilerin yüzeysel olduğu görüşüne sahiptirler.

Çoğu zaman insanlar kişisel olan konularda kendilerine soru sorulmasından pek hoşlanmazlar. Bunların sorgulanmasını kişilik haklarının ihlali olarak düşünürler. Yapılan çalışma sonucunda elde edilen bulgular incelendiğinde bu durumun bir yansıması görülebilmektedir. Katılımcılar kişisel bilgilerinin sorulmasının rahatsızlık duyduklarını, bu madde ile ilişkili olarak açığa çıkmaktan endişe duyduklarını dile getirmişlerdir. Bu konu ile ilgili olarak İslamoğlu (2002; 73), anketler aracılığıyla, kişilerin “gelirleri, tuttukları siyasi parti, alkol kullanıp kullanmadıkları, namaz kılıp kılmadığı vb.” konular ile ilgili, istenilen bilgilerin bazen katılımcılar tarafından verilmek istenmediğini ve bu türden bilgilere doğrudan sorulan sorularla ulaşmanın imkânsız olduğunu belirtir. Benzer bir şekilde Dawson (2002), bazı soruların hassasiyetinden dolayı bu soruları doğrudan katılımcıya yöneltmek yerine dolaylı bir şekilde, cevabın diğer insanlarla ilişsilendirilebilecek şekilde, sorulmasının daha iyi olabileceğini belirtir. Bu konu ile ilgili olarak Büyüköztürk ve diğ (2016)., rahatsız edici soruların erken ortaya çıkmasının katılımcının soruları cevaplamaktan vaz geçebilmesine neden olabileceği ihtimaline karşın kişisel ve gizlilik gerektiren soruların anketin sonuna yerleştirilmesi gerektiğini önermektedir. 
Yüzüncü Y1l Üniversitesi Eğitim Fakültesinin bazı bölümlerinde okumakta olan öğretmen adayları ile yapılan bu çalışmadan elde edilen bilgiler için sonuç olarak öğretmen adayı olan bu öğrencilerin anket çalışmaları konusunda hassas davrandıkları, bu türden çalışmalarda elde edilen bilgiler yüzeysel olsa da sosyal bilimlerde veri elde etmede önemli bir araç olduğunun bilincinde oldukları ve bu bilinç ile anket formundaki maddeleri okuyarak gerçekçi yanıtlar verdikleri söylenebilir. Ayrıca katılımcıların, soruların daha gerçekçi cevaplanabilmesi için, uygulanan anketler hakkında kendilerine daha fazla bilgi verilmesi konusunda bir beklenti içinde oldukları da ifade edilebilir.

Bu çalışmadan elde edilen bulguların 1şı̆̆ında aşağıda belirtilen öneriler yapılabilir:

1. Özellikle eğitim bilimlerinde yapılan araştırmalarda sıklıkla anket veya ölçekler veri elde etme aracı olarak kullanılmaktadır. Ancak bu araştırmaların birçoğunda bazı öğrencilerin çalışmaya karşı ilgisiz oldukları ya da soruları rastgele cevaplamış oldukları görülebilmektedir. $\mathrm{Bu}$ da araştırmacının çalışmanın güvenirliği konusunda endişe duymasına neden olmaktadır. Ancak bu araştırmada yer alan öğretmen adaylarının anket çalışmaları ile ilgili görüşleri olumlu yöndedir. Bu nedenle sosyal bilimlerde ve eğitim bilimlerde anket yöntemi ile veri elde etmenin öneminin bilincinde olan öğretmen adaylarından elde edilen verilerin güvenirliği konusunda ön yargılı davranılmaması ve bu kaygının gereksiz olduğu görülmektedir.

2. Yapılacak olan çalışma ile ilgili ve uygulanan anket formları hakkında, araştırmacı ya da anket uygulayıcısı tarafından, katılımcılara yeterli düzeyde bilgi verilebilir. En azından bu amaç için anket formu bir açıklama ve yönerge ile başlatılmasına dikkat edilmelidir.

3. Kişisel bilgilerin yer aldığı çalışmalarda bu bilgilerin neden önemli olduğu hakkında katılımcılara bilgi verilmelidir. Yapılan çalışmadan elde edilen verilerin nerede ve hangi amaçla kullanılacağı ile ilgili katılımcılara bilgi verilmelidir. 
4. Yapılan bu çalışma eğitim düzeyi yüksek olan bireyler ile gerçekleştirilmiştir. Benzer çalışmaların farklı eğitim seviyelerinde de yapılarak katılımcıların anket uygulamaları hakkındaki görüşlerine ulaşılabilir.

5. Özellikle konusu insan olan çalışmalarda elde edilen bilgilerin sürekli değişkenlik gösterebileceği göz önünde tutularak bu tarz çalışmalar belirli aralıklarla tekrarlanabilir.

\section{Makalenin Bilimdeki Konumu (Yeri)}

Eğitim Bilimleri / Eğitimde Ölçme ve Değerlendirme alanları

\section{Makalenin Bilimdeki Özgünlüğü}

Anket formları veya ölçekler kullanarak veri elde etmek, Eğitim Bilimlerinde ve diğer Sosyal Bilimlerde önemli bir veri elde etme aracıdır. Ölçmede kullanılan aracın niteliği ve ölçülen kişi ise güvenilir veri elde edebilmenin ve dolayısıyla yapılacak olan araştırmaların güvenilir olmasının önemli kaynaklarıdır. Bu yöntemle elde edilen verilerin güvenirliği, cevapların rastgele verilen cevaplar olup olmadığı, katılımcıların anket formlarını doldururken gerçekçi olup olmadığ çoğu zaman araştırmacının aklında bir soru işareti olabilmektedir. Bu bağlamda belirli aralıklarla katılımcıların kendilerine uygulanan anket formları hakkındaki görüşleri üzerinde yapılacak çalışmaların, uygulanan anketlerin daha işlevsel hale gelmesinde özellikle araştırmacılara yol gösterici önemli katkılar sağlanması beklenmektedir. 


\section{Kaynakça}

Altunışık, R. (2008). Anketlerde veri kalitesinin iyileştirilmesi için öntest (Pilot Test) yöntemleri. Pazarlama ve Pazarlama Araştırmaları Dergisi, 2, 1-17.

Balc1, A. (2010). Sosyal bilimlerde araştırma. Ankara: Pegem Akademi.

Berner, M., Bowers, A., Heyman, L. (2002). So you want to do a survey.... Popular Goverment, Summer, 23-27.

Büyüköztürk, Ş., Balcı, E.K., Akgün, Ö.E., Karadeniz, Ş. ve Demirel F. (2016). Bilimsel araştırma yöntemleri. Ankara: Pegem Akademi.

Çilan Arıcıgil, Ç (2009). Sosyal bilimlerde kategorik verilerle ilişki analizi. Ankara: Pegem Akademi.

Dawson, C (2002). Practical research method. United Kingdom: How To Books Ltd.

İslamoğlu, A.H. (2002). Bilimsel araştırma yöntemleri. İstanbul: Beta Yayınları.

İslamoğlu, A.H. (2011). Sosyal bilimlerde araştırma yöntemleri. İstanbul: Beta Yayınları.

Karasar, N. (2008). Bilimsel araştırma yöntemleri. Ankara: Nobel Yayın.

Oğur, R ve Tekbaş, Ö.F. (2003). Anket Nasıl Hazırlanır?. Sted, 12(9), 336-340.

Sönmez, V. ve Alacapınar, F.G. (2014). Örneklendirilmiş bilimsel araştırma yöntemleri. Ankara: Anı Yayınları.

Ünsal, P. (2003). Örgütsel araştırmalarda anket yöntemi. Ankara: Çantay Kitapevi. 


\section{Summary}

\section{Problem Statement}

Nowadays, survey studies are one of the important research methods which are used to collect data from primary sources and to standardize observations in many fields, especially educational and social sciences (Oğur ve Tekbaş, 2003; Balc1, 2010; İslamoğlu, 2011). The questionnaires, used in the researches, should be appropriately prepared to be valid. Giving information about the content of the questionnaire to the attendee is important to attract the attendee's interest. However, these informations should not direct the participant, they should be about the concept of the study (İslamoğlu, 2002).

In order for the results obtained to be reliable, the data used in the research must be reliable. Appropriateness or "excellence" of the analysis methods applied to the data does not compensate the mistakes which are results of data (Altunışık, 2008).

The reliability of the work depends on the sensitivity of the participants involved in the research. Misleading or never understood questionnaires, reluctance to answer, incomplete reading or answers without reading cause collected data to be wrong and therefore the information obtained from these data to be incorrect (Altunışık, 2008).

For some topics such as belief, health, political party which they vote or topics about personal life, participants may not be able to be frank (İslamoğlu, 2011). This can affect negatively the reliability of the work performed.

By collecting data through a questionnaire, researchers can often be prejudged about that, answers given to the questions were not realistic; it was intervention for the special life; the 
questions did not reflect their own opinions; especially in the graded options the participants pointed out the same option in all questions.

\section{Purpose of the study}

The purpose of this study is to examine the opinions of the participants about the questions in survey applied to them.

\section{Method}

The screening model was used in the study. The data were obtained voluntarily from the students who are studying in Psychological Counseling and Guidance (PDR), Classroom Teacher Education, Computer and Instructional Technologies (BOTE), Music and Pre-school (OÖ) in Yüzüncü Yıl University of Faculty of Education. The measure tool was applied to 148 students in total. To obtain the data, a survey form prepared by the researcher was applied. In the survey, there were eight questions to obtain participants' information, and 30 questions to get their opinion about questionnaire applications. In the analysis of the data, "Cross Tab" method was used. The significance level of the relationships was determined by using chisquare test and the alpha significance level was taken as .05. The "Fisher's Exact Test" value was used in the case that observations in the cells were less than five.

\section{Findings and Discussion}

Participants in the study indicated that they were being realistic during answering the questionere including questions about health and family life and they obeyed the data collection methods in an accurate way.

When the relationship between "the reality of the answers given to the questionnaires" and "answering the questions without reading to finish survey quickly" is observed, the participants 
stated that they did not agree both statement substantially. Participants stated that they have read the questions even if the number of questions were high. The fact that participants responded similarly to questions of similar nature shows the consistency of their realistic behaviors.

Information indicating that participants were being careful while answering every question was gathered. Participants who said that they read the questions without haste, expressed that they read the questions even if the number of questions is too many, they are aware that the questionnaire is an important tool in collecting data and they respond realistically. One of the items related to the article "I mostly don't read the questions to finish the questionnaire quickly" is "I will try to give realistic answers if enough information is given about the questionnaire content". This shows the importance of informing the participant about the research topic in order to obtain reliable data.

To obtain qualitative data from survey applications, giving enough information about the importance of the topic of the study is crucial for reliable information. It was observed that participants were aware of the importance of the topics of survey when they filled out the questionnaires given to them, and they were aware that the quality of these kinds of studies could clarify the questions about the issues of interest to society.

\section{Results and suggestions}

It can be said that for the results obtained from this study, as a result, students are sensitive about survey studies; although the obtained information in this kind of studies are superficial, students are aware that this information are an important tool to obtain data in the social science, and they give realistic answers by reading the questionnaire items with this awareness. It can 
also be said that the participants are expecting more information about the applied surveys, to be able to answer questions more realistically.

According to the findings obtained from this study, the following items can be suggested:

* The participant can be adequately informed about the study and about the applied questionnaire, by the researcher or surveyor. At least, the questionnaire can be started with an explanation and directive for this purpose.

* Participants can be informed about why this information is important, when their personal information is used. The participants should have the information on where and for what purpose the data obtained from the study can be used.

Keywords: Survey, participant, reliable information 